\title{
DECOLONISING HIGHER EDUCATION RESEARCH: FROM A UNI- VERSITY TO A PLURI-VERSITY OF APPROACHES
}

\author{
C. Martinez-Vargas \\ Higher Education and Human Development Research Group \\ University of the Free State \\ Bloemfontein, South Africa \\ e-mail: MartinezVargasC@ufs.ac.za
}

\section{ABSTRACT}

Decolonial rhetoric has enveloped the South African academic world advocating for cognitive justice. Debates have increased exponentially, highlighting the complexities of the theme and the diversity of positionalities towards a decolonial solution. Thus, the imperative responsibility to explore the debates and participate in the active networks towards a partial solution has become clear.

Therefore, this article explores the decolonial literature. It introduces the complexities of the epistemological field and upholds a pluri-versity of approaches. In this university converted into a pluri-versity, practices should be diverse in form and content, including knowledge systems historically excluded, but equally preserve those that, although imposed, should still be present for an ecology of knowledges. To do so, I argue that despite the use of African or indigenous methodologies being used as a way to decolonise research, we need to increase the use of participatory methodologies, in their diverse forms. Thus, diversifying our practices as researchers and combining them with traditional research practices is the only way to promote a pluriverse which is nurtured by diverse knowledge systems on our way towards decolonisation.

Keywords: decolonisation, higher education, participatory approaches, ecology of knowledges, pluriverse

\section{INTRODUCTION}

Higher Education institutions form a complex and diverse global epistemic system. To date, to a great extent, they have managed to bring together, different groups to generate knowledge and to work together. Even though these working relations have been successful in many ways, there have been many challenges, especially for institutions in the Global South, as in South Africa. Thus, constant evaluations are necessary to improve it. The institution in which I am based, is a good example. It has changed from accommodating predominantly white students to have a majority of black students, as well as improving their language policies. Equally, albeit more slowly, staff members are changing being more inclusive to the diversity of the continent. All these changes impact the way we produce knowledge in our institution, but also why and how we talk about decolonisation. Thus, although processes of knowledge production 
rooted in colonial logics still prevail, alternative approaches to research also develop, asking us to rethink our higher education institutions.

Further, student protests demanding the decolonisation of their educational institutions indicate that we are currently living challenging times, and it is the moment for change. That is why decolonial strategies have been developed across the country in different ways and forms. I intend to argue in this article that these different ways and forms of knowledge generation are situated in the right direction when we aim to reduce knowledge inequalities and promote the decolonisation of South African higher education institutions.

\section{FORWARD, BACKWARDS, OR BOTH?}

Higher education institutions have historically been a space of domination while also a platform where counterhegemonic discourses have emerged (Castells 2001). Indeed, in contexts as South Africa, what universities teach, under which epistemic systems, how and by which scholars are central questions to think about decoloniality and decolonisation (De Sousa Santos 2006b; 2012; Hall and Tandon 2017). And this is what protest as \#FeesMustFall or \#RhodesMustFall have started to question. First, demanding measures against the commodification of universities and secondly, critiquing the colonial heritage of their institutions. Thus, South African universities clearly are a space of struggle, a space of decolonial conflict (Becker 2016; Bosch 2017; Luescher, Loader and Mugume 2016; Naicker 2016). These colonial difficulties are equally, reiterated by different scholars. For instance, Kovach (2012) highlighting that "the decolonisation of the African Academy remains one of the biggest challenges, not only in terms of the curriculum, teaching strategies, and textbooks, but also in terms of the democratisation of knowledge, and the regeneration and adaptation of old epistemologies to suit new postcolonial realities" (Emeagwali and Dei 2014, 4). Therefore, if we want to decolonise higher education institutions, we need not only to promote curriculum changes, but we need to reconsider the Eurocentric onto-epistemology of these institutions. This Eurocentric ontoepistemology, a hegemonic perception of reality, is detached from humans, an objective and universal worldview, that assess knowledge according to its own standards of truth and thus, ignore other knowledge systems (De Sousa Santos 2006b). Shizha (2014) reiterates that indeed we have a colonial European higher education system in South Africa. These institutions are in contradiction with the cultural capital that students bring with them to their institutions, therefore, generating many challenges as educational failure, emotional distress or identity problems. They do alienate its university student body from their cultural background.

Equally, Obiokor (2014) identifies similar challenges in the Nigerian educational system, claiming that students are blamed for their inability to assimilate their colonial culture. For 
Obiokor (2014), the main issue is that this imposed Western education system is disconnected from their local cultures but also detached from the autochthonous values and cultures. Wa Thiong'o (1994) claims that educational institutions are racial spaces that preserve colonial hierarchies, they maintain "ideological apartheid", especially in their higher education institutions. Moreover, Dei (2014) reiterates the need for the transformation of the educational systems in Africa, introducing indigenous knowledges as a way to decolonise our institutions because curriculums still negate their Africans roots. Shiza (2014), equally, supports a pedagogical change. The author advocates for an educational reform able to value students' knowledges. The integration of local knowledges allows the students' cultures, languages, values and worldviews to be integrated in the way of learning.

However, we should not fall into the extremist trap, neither the oversimplification of our universities and their knowledge generation techniques. Indeed, our educational system is not homogenous; our institutions are complex systems with many contradictions for the bad and the good (Castells 2001). That is why, I argue in this article that the Western epistemic system is still needed. However, we still have to balance knowledge inequalities in our Southern institutions, being able to create a pluri-versity able to embrace the diversity of worldviews around the world, including our African and South African worldviews. To do so, I will first address decolonial literature, precisely two substantial points: colonialism and modernism, to understand how the system of science was developed and imposed to others and how a decolonial strategy might look drawing from a colonial uni-verse to a decolonial pluri-verse.

\section{COLONIALISM AND MODERNISM IN WESTERN RATIONALITY}

Colonialism and modernism are usually referred in the literature as the two historical processes in which the Western block - North Atlantic block (Mignolo 2008) - expanded its power and cultural influence across different continents (Parra-Romero 2016). This expansion is often understood beyond a territorial conquest by postcolonial scholars and refer to intellectual and political exploitation (Chilisa 2012; Wa Thiong'o 1994). Chilisa (2012) characterises colonialism as "a brutal process through which two-thirds of the world experienced invasion and loss of territory accompanied by the distribution of political, social, and economic systems, leading to external political control and economic dependence on the West" $(2012,29)$. Therefore, the loss of local cosmovisions and beliefs in addition to the territorial conquest. Wa Thiong'o (1994) adds that colonialism appropriated the wealth of local societies, understanding wealth broadly, as goods and territories but also imposing their colonised worldview to these societies. Thus, establishing their cultures, languages, political systems, institutions as the unique way to organise and behave in their newly renewed "modernised" nations. It was a 
psychic and mental imposition.

The creation of the "other" was part of this conquest and imposition of Western culture. The "other" was created by Europeans to undervalue local communities, as opposed to their own superiority (Chilisa 2012). Local communities were mere objects to them, an object to be defined and observed by European standards (Semali and Kincheloe 2002). These territories were unhuman, inhabited by irrational and savages beings that contrasted with the developed modern world in the West (Fanon 2007). Further, two significant elements led them to believe in the inferiority of these local communities, the absence of an alphabet and the integration with nature of these individuals; both used to claim and sustain European superiority throughout centuries. For example, naming them as "innocent children" needed of a religion, as Christianity as claimed by Bartolome de las Casas (Mignolo 2007).

This shared understanding of native communities as inferior created a lawless zone (Zibechi 2015). It did situate local communities beneath European law, hence, European were allowed to kill; however, this was not considered as a crime (Mbembe 2011).

The "other" was then conceptualised as a monolithic and static romanticised object due to all these Eurocentric interpretations. At the same time, Europe was starting its modernist phase, a phase characterised by imposing reason over tradition (Ranger 1997; Parra-Romero 2016). However, the linear transition from colonialism to modernism is a point of discrepancy among scholars. Some scholars suggest that modernism did not start in the eighteenth century, as many have claimed, with the Enlightenment period. Contrary to this, Dussel (2007) confirms that this modernist phase began with the discovery of America. Further, the point for him is that modernity, European empires, colonialism and the capitalist system were part and parcel of this social phenomenon, being connected and working together recentering the global power in the West and thus, conforming the actual hegemony (Dussel 2007). Modernity for Dussel (2000) is Eurocentric because of the events before the Enlightenment period. He claims that the reason why the West block became a hegemony was and still is, its universalist worldview imposition to all. Following these ideas, Mignolo (2007) clarifies that modernity was created against the traditional view of the colonies, and not as a continuation of the Middle Ages, as many scholars attest. Therefore, all the colonial territories were considered as backwards, and barbarians compare with the modern evolution of the West, not fitting into the contemporary regulations and mindset of the colonisers (Lander 2000; Castro-Gomez 2000).

On the other hand, Mbembe (2011) exposes the same challenges, however, from a Foucaultian perspective, centring his argument on the relation between race and colonialism and how natural sciences has determined biological groups and subgroups to classify populations. Mbembe (2011) uses the concept of biopower to understand colonial structures of 
power and domination; thus, the construction of the other opposite to the European societies. In essence, these modernist logics develop into modern sciences, understanding an objective reality detached from human beings, but also imposing universal laws for all, irrespective of our locations.

Hence, colonialism is indeed a present challenge according to many postcolonial scholars. It is an urgent issue that needs to be addressed, and they use different ways to name it, although their meaning is still the same, the oppression of the hegemony over the "other". Neocolonies is used by Wa Thiong'o (1994) to refer to the actual abuse of the periphery, following the identities, cultures and institutions established by the colonisers. Equally, postcolony is used by Mbembe $(1992,3)$ to name the "regime of violence" on these old-colonial locations and how identity assimilation still the norm even today. For him, it is a colonised consciousness, an imposed system of oppression that has been internalised. Hence, local populations follow without questioning this oppressive system, as it became invisible to them. Neocolonial territory is used by Appiah (1993) as well, referring to the marginalisation of these communities and the negation of their own history and languages. Their identities can only be through the coloniser's cultural codes, reproducing colonial languages and colonial figures. For Dei (2014), it is also about neocolonial territories from a Fanonist perspective, describing the colonial challenges in our societies, therefore, in order to initiate a change, we will need to critically explore our past to understand what is still oppressing us.

In conclusion, the point to be made by many of these postcolonial scholars is the imposition of the Eurocentric worldview, the universal hegemonic worldview to all. This universal worldview is inspired by the Cartesian ontological rift, which provided a compendium of laws that organised nature and other human beings as detached from body and context and arranged them hierarchically. Thus, claiming a universal and objective representation of the world (Dussel 2007; Lander 2000; Castro-Gomez 2000). Moreover, a Eurocentric interpretation of the world that represents a linear evolution of societies, determining the Western block as the most advance position of all, and for us in the South to follow. Thus, a global and universal way to understand progress and development, in which we are already situated in a disadvantaged position (Lander 2000).

\section{EUROCENTRIC KNOWLEDGE}

The geopolitics of knowledge, here referred to as the knowledge power structures - whose knowledge matters and why - has been central to many scholars when understanding knowledge inequalities. In this area, Whitt (2009, xiii-xiv) asserts that "the conduct of imperial science by nation-states during the late eighteenth and nineteenth centuries, and its effect upon 
other nation-states, has led historians of science to conclude that the issue is no longer science in imperial history but science as imperial history". Whitt (2009) explores the domination of natural science over other knowledge systems, highlighting its cultural and economic hegemony, bringing the difficulties that indigenous knowledge systems experience to access mainstream knowledge production channels in academia, as an example. The author asserts that the domination of the positivist paradigm in Western science does not allow to conduct research in different ways than its own positivist methodological assumptions.

On the other hand, another group of scholars does not focus on the exclusion but the appropriation of local knowledges. In this way, their argument claims the historical appropriation of different knowledges from other civilisations by Western countries throughout history, not being this adequately acknowledged or recognised. They challenge the male, white, adult origin of Western civilisation, culture and knowledge (Semali and Kincheloe 2002; Appiah 2010; Diop 2010), claiming that Western civilisation refuses to acknowledge its black origin from our biological chain, the blackness of Egypt and the link from Egyptian knowledge to the Greece civilisation (Diop 2010). Further, the point is not only being incapable of recognising the black origin of Western science but the pervasive negation of African history, the history that was never allowed to be told and narrated. However, some scholars have merged both positions as Smith (1999) does, clarifying that the issue relies on both aspects the appropriation and the domination with its current epistemic system.

Nevertheless, such static divisions between the European knowledge and other knowledges or perfectly linear transitions between diverse civilisations and knowledge are challenging, due to the global conditions in which we live and the constant interaction among epistemic communities and its cultures. That is why scholars have explored these divisions. For instance, De Sousa Santos (2006a) claims that when we refer to South or North, there is not a clear, static division, not even a territorial division. The point is to highlight the ontological and epistemological rift, which is geopolitical. This division represents a geopolitical space guided by underlying logic that can be found physically in the North of the South (De Sousa Santos 2015). Hence, as well as De Sousa Santos (2006a), Whitt (2009) investigates these divisions as scientific vs traditional, North vs South or Western vs Indigenous. He claims "I have in mind a reasonably specific but enormously influential strain of the Western intellectual heritage. Referred to as "positivism" in its earliest incarnation, I am more concerned here with its current "neo positivist" manifestation. Although purportedly dead as a movement, the spirit of positivism continues to haunt much of Western science and philosophy" (Whitt 2009, xvi).

Additionally, many scholars rightly refuse to discredit Eurocentric knowledge, for them what is necessary is to critically analyse its universality, as well as its white, European, male 
construction (Soldatenko 2015). This imposed universality over other territories and cultures is called "zero-point" as a way to understand "the imaginary position of those who claim neutral objectivity for themselves, an unseen position that presumes to see all" (Castro Gomez cited in Soldatenko 2015, 140). Therefore, scientific knowledge, Western knowledge is established as a unique and universal way of producing knowledge, a colonised epistemic system that does not understand its own universality and its imposition to others (Parra-Romero 2016). Equally, it does not recognise knowledge that is situated on the other side of the epistemic line. An example of this could be the continuous scientific validations that indigenous knowledges have to go through to be considered as valid and rigorous. Indeed, this inability to recognise other knowledge systems jeopardise the richness of global human knowledge and wisdom beyond Western knowledge (Zibechi 2015). It is epistemological blindness, as Hleta (2016) claims; or an epistemicide as De Sousa Santos (2015) calls it, a murder of knowledge. It imposes the Western epistemological cannon extinguishing local knowledge systems and its social practices.

Therefore, the argument about domination and appropriation highlights the contribution from these authors to challenge colonial discourses, including its claimed universality and neutrality (Girei 2017; Escobar 2007). The Western epistemic system is more than an epistemic system in itself; it establishes what is the good and what is the bad, and therefore develops an idea of social progress and its political system and institutions (Foucault 1982; 2002; Derrida 2003; Soldatenko 2015).

\section{FROM COLONIALITY TO DECOLONIALITY: THINKING OTHERWISE}

After reviewing the different positionalities about colonial structures of knowledge generation, explored in the previous section, what is clear is that the literature highlights the imposition of a Western system, incapable of recognising its own limitations. It establishes an ontoepistemological understanding of reality, ignoring other knowledge systems and the richness of human wisdom beyond its Eurocentric centre. Nevertheless, although the challenge is clear, the solutions and perspective to decolonised our knowledge generation processes and our institutions are different among scholars, having different nuances and levels. First, we observe how some scholars talk about decolonisation from an individual approach. That is the case of Dei (2014) that argues for individual responsibility, an interrogation of our colonial codes and the implication of these in our way of thinking but also our collective participation in our societies and the interaction with our institutions.

Alternatively, the majority of positionalities regarding decoloniality and decolonisation do not identify a clear object to be responsible for the decolonial process, but rather focus on 
elements - cognitive or physical elements - that need to be challenged and then decolonised. Thus, suppressing cultural aggression for Diop (2010), decolonising our consciousness as Ceraire (2000) claims, challenging the imposed Western cosmovision with its norms, values and customs; or finally providing a series of steps from identification to final action phase in order to achieve decolonisation, as Emeagwali and Dei (2014) investigate.

On the other hand, there is another important line of thought composed by indigenous researchers. In this approach, they recognise similar challenges regarding the domination and appropriation of indigenous knowledge systems (1999). However, they claim that inclusion of indigenous knowledge systems will not be sufficient to overcome their epistemic marginalisation, due to the blindness of Western science and its inability to understand the value of indigenous knowledges (Dei 2014). For them, indigenous knowledges are able to question the "Cartesian Newtonian epistemological foundationalism" (Semali and Kincheloe 2002, 17), visualising the underlying politics of knowledges, as the imposition of a unique truth and its universalism. Further, they attest that the better example to see the limitations of the Western system is the global ecological crisis, in which indigenous knowledges have proven to be much more efficient to understand and address the challenge than Western science.

Nevertheless, in this article I strongly support the Border-hegemonic movements and "pluriverse" project sustained by various authors (see Dussel 2007; Boidin, Cohen and Grosfoguel 2012; Escobar 2018, among others). Firstly, despite the importance of the indigenous movement, the indigenous category might jeopardise other decolonial approaches that are not necessarily indigenous in form, despite being equally oppressed by the Western epistemic system. Thus, the border-hegemonic movements refer to a variety of individuals and communities that have been excluded due to their differences and dissent from the hegemonic system (Dussel 2007). They are excluded and marginalised by the Western system due to their colonial, capitalists, patriarchal, sexist, heteronormative and racist logics. Hence, here we can find excluded groups as LGBTQI movements among many others.

The "Border-hegemonic movements" are defined by Dussel (2007) as a "subjectivity of intersubjectivities". These terms refer to the transition from a unique objective perception of reality - uni-verse - to a subjective one, which is composed by a plurality of subjectivities pluri-verse -. The intersubjectivity concept seeks to embrace all the Border-hegemonic movements, such as African, feminist, indigenous or LGBTQI movements, not unifying them but preserving them as plural and diverse in their way to understand their own struggle under different perspectives. Dussel (2007) explains how the Border-hegemonic movements have led the fight against inequalities and fostered solidarity for marginalised groups. For instance, the French Revolution, but also more actual example as feminist movements or African movements 
and their role in the promotion of freedom for their respective groups. Thus, the preservation of diversity among these groups is part of the pluri-verse project. It is the transformation from a uni-verse which is totalised and homogenous - the Western project - to a pluri-verse that is able to preserve the heterogeneity of the world, its worldviews and epistemic systems.

Nevertheless, vigorous criticism should not advocate for radical perspectives by ignoring the value of Western knowledge, its culture and the promotion of border-hegemonic movements fighting against injustices (Dussel 2007). In this case, it is relevant to acknowledge the gains due to Western science and how we have benefited from them, as the increase of a global average of life expectancy due to advancements in Western medicine (Riley 2001). The point as mentioned in previous sections is to do not radicalise our positions and think that everything produced by the Western system is terrible, thus a colonial imposition, or that every knowledge excluded by the Western system is good and thus, glorified. Both the Western epistemic system with its wrongs and goods as well as excluded epistemic systems need to be critically analysed. Not all the practices and thinking rooted in the North are automatically an attempt to colonise us, despite that might be in many cases (De Sousa Santos 2015). Therefore, we need to identify epistemic injustices in one and the other side of the hegemonic epistemic line, contrary to develop a new hegemonic system that repeats the same mistakes as Western sciences (Hleta 2016). It is a matter to critic knowledge inequalities and promote border knowledge under an ecology of knowledges - a combination of knowledges -.

\footnotetext{
"Keeping distance does not mean discarding the rich Eurocentric critical tradition and throwing it into the dustbin in history, thereby ignoring the historical possibilities of social emancipation in Western modernity. It means, rather, including it in a much broader landscape of epistemological and political possibilities. It means exercising a hermeneutics of suspicion regarding its 'foundational truths' by uncovering what lies below their 'face value'. It means giving special attention to the suppressed or marginalised smaller traditions within the big Western tradition." (De Sousa Santos 2006a, 73-74).
}

Hence, it is indeed virtuous to support a specific cosmovision; the injustice occurs when it is imposed on other communities or societies, and this is done under oppressive practices. For instance, saying that is on the name of God, or any other superior entity as Western reason, pretending that is better than any other kind of reasoning (Mignolo 2007). In brief, decolonisation is not substituting one hegemonic system for a new one represented by a single ethnic group but rather, being able to put into value different perspectives and thus, epistemic systems. In this plurality, we will be able to develop new and alternatives towards modernity and its subsequent neoliberal order.

Further, we cannot forget that to do so; we will need democratic spaces allowing partial knowing positions. De Sousa Santos (2010) refers to partial knowing positions as a way to 
understand the internal and external limits of every knowledge system. ${ }^{1}$ Thus, if every knowledge system is limited in a certain way, the system is composed of partial knowing positions that need one to another. The incompleteness of all knowledge systems forces to an epistemic dialogue between these different knowledges. Moreover, the question lies in finding ways to introduce platforms that can sustain dialogues between knowledges. These dialogues would allow us to transform a homogenous uni-verse into a diverse pluri-verse as a form of decolonisation.

\section{A PLURI-VERSITY OF PARTICIPATORY METHODOLOGIES, METHODS AND RESEARCH PROCESSES TOWARDS DECOLONISATION}

Global academia is now more diverse than ever, challenging in many ways traditional approaches to research, and thus, underlying assumptions about objectivity and scientific reasoning and universality (Lander 2000). These alternative research practices help us not only to investigate the limitations and pitfalls of the actual system but to extend our research presenting alternative paradigms, methodologies and methods that deeply reform our inquiries. That is why Lincoln, Lynham and Guba $(2011,97)$ state that "inquiry methodology can no longer be treated as a set of universally applicable rules or abstractions", we are, indeed, as the authors claim in a time of paradigmatic controversies and contradictions. And in this new paradigmatic space is where we find decolonial research processes that can assist us in promoting change from within academia, promoting ecology of knowledges and the advancement towards a pluri-verse, although this is not done without challenges (Girei 2017). There are two main areas I would like to consider here, first the indigenous line of methodologies, and somewhat similar, a second line composed of participatory approaches as decolonial pathways in research. Both lines, promote the advancement of a pluri-versity of strategies in higher education necessary to decolonise our institutions in different ways and forms. Indigenous methodologies, are situated in the indigenous studies field, usually supported by indigenous scholars from the Global South. In this type of methodologies, local communities are not seen as objects but as participants able to determine their own investigative techniques. Therefore, they usually apply rooted indigenous methods that does not distort the collection of data, either the analysis of it. Alternatively, and being the focus of this section, we find participatory approaches, as Participatory Research (PR) or Participatory Action Research (PAR). This family of approaches initially born in the North with practices as Action Research (AR) acquired a more radical approach when used in the South, providing similar ideas as what the indigenous family identify as critical challenges. Both lines, challenge in one or another way Eurocentric assumptions and provide us with research practices able to advance towards 
decoloniality and a pluri-verse of approaches.

Therefore, in the African line of indigenous methodologies, the main feature is, as mentioned above, the reformulation of the inquiry process under the local worldviews, where the research is applied. Thus, taking into consideration, cultures, beliefs and values. In this case, African centred methodologies or Indigenous African research processes are proposed as specific to the African contexts (Dei 2014). Equally, Emeagwali and Dei (2014) talk about indigenous research as a way to decolonise Western science and to challenge the Eurocentric dogma. It is through this type of research that other methodologies and methods can advance epistemic justice and the democratisation of knowledge. Further, focusing on decolonising methodologies, Smith (1999) argue to challenge how we research, questioning how we interact with communities and individuals, how we frame our research issues, and how we make decisions about our research topics. Hence, she proposes that in order to decolonise traditional academic methodologies, it is needed to respect and understand other knowledge systems, especially when working with indigenous or other local communities, thus, articulating an ecology of knowledges throughout our research projects.

Nevertheless, despite that indigenous research and methodologies are usually the practices associated with decolonial research practices, being the most widely known typologies in the literature to advance decolonisation, other methodologies, research methods and inquiry processes that are less acknowledged but which possess substantial potential are present today in our academic institutions, such as participatory approaches.

Using the concept of participatory approaches, I refer here to different methodologies and methods that involve communities in the process of research at different levels and implemented in diverse forms. This scholarly family of approaches started in the early 1940s, challenging some of the Eurocentric assumptions underlying research until then. Thus, questioning in some cases, its universality and objectivity, as irrational Cartesian doctrines. Nevertheless, these type of practices, although crucial for decolonisation has not always been at the centre of these debates and as a possible way to address these colonial challenges. Indeed, the beginning of participatory approaches in Europe is complicated and probably visibly detached from critical approaches to research, as its theoretical influences were clearly Eurocentric. However, and despite this initial development, more critical practices were added to the family, bringing more radical perspectives and alternative methods. That is why this section is divided into three research lines within participatory approaches that are not pure but interwoven, in order to present them as feasible alternatives towards decolonisation. These are the development, industrial and educational research lines, in which now I elaborate.

The first research line is the represented by the development line of participatory 
approaches. This line started around the 1960s in the Global South simultaneously in continents like Asia, South America or Africa. The primary terminology associate with this practice is Participatory Action Research or Participatory Research, although there are disagreements of who used it first or created the terms. Two prominent figures in this area are the most commonly referred to as their precursors: Fals Borda and Marja-Liisa Swartz (Nyemba and Mayer 2017; Thiollent and Colette 2017). Fals Borda is referred as the creator of participatory research and Marja-Liisa as the one that working in Tanzania developed participatory action research in the late 1970 s.

As the leading figure of this family, Fals Borda in Colombia is well known for his defence of the philosophy of the liberation and Freirean ideology (Brydom-Miller 2001). His research based on these assumptions aimed to prompt the emancipation of oppressed communities (Kindon, Pain and Kesby 2007). The research process was understood as a liberation practice and applied mainly in oppressed communities (Fals Borda and Rahman 1991). For him, community members were "sentipensantes" - thinking feeling individuals - and therefore, both reasons and emotions were part of the research process through empathetic engagement. Doing so, the combination of different knowledges, especially knowledges from marginalised communities were central to the investigative techniques that he used. His research merged rigorous data collection with the participatory process, as Rappaport (2017) asserts. The community was actively involved in deciding the theme, the agenda of the research and they were the ultimate owners of the results. In this way, the results were understood as a political tool. The process, thus, was a communal self-reflection, in which an ecology of knowledges was articulated combining academic and grassroots research, it was a "dialogo de saberes" knowledge dialogue -. Contrary to Fals Borda, other practitioners contemporary to him, as Vasco Uribe were known to use more radical approaches. In this case, rigorous data collection or systematic analysis were not required, as the process was a space to share and think together with the community available epistemic materials (Rappaport 2017).

Secondly, Action Research is mostly known as the first typology in the field of participatory approaches, as it begins in the 1930s with scholars as Kurt Lewin (Adelman 1993). Nevertheless, it is well known that Action Research as conceptualised by Lewin was based on pragmatism and industrial efficiency. Lewin was a psychologist investigating about social change and habits. He wanted to understand how to change practices in specific populations. However, as part of his work, Lewin started studying how to improve productivity in factories impacting absenteeism (Greenwood and Levin 2007; Krisitiansen and Blosch-Poulsen 2016). In this way, Lewin is the precursor of a line of Action Research that was changing certain assumptions about conventional research, as he included participants in the research process 
and with the years his practices became more a more critical (Rappaport 2017). Thus, although this line is considered the most conservative among participatory approaches, it is undoubtedly true that without the initial questioning of Lewin, many other practices will not have been possible. Either truly critical applications of Action Research that many scholars use nowadays - diverging from Lewin's initial conceptualisation - to challenge Eurocentric ways of researching (Adelman 1993).

Finally, we have the educational line of participatory approaches with Educational Action Research (EAR) as its main category. In the Educational Action Research family, we find many other terminologies as Action Learning, PALAR, Classroom Action Research, among many others. This line embraces many types of practices usually based on educational contexts and institutions. Hence, it is common to find projects as based on primary, secondary or tertiary educational institutions focusing on the improvement of pedagogical practices or on particular issues that affect those institutions (Noffke and Somekh 2009). These research processes are influenced by the Action Research family. Thus, its implementation would usually go through cycles of action and reflection to prompt a change, and practices can range from more individual processes to a more participatory and engaged inquiry.

These three research lines of participatory approaches present very different practices from more conventional applications, as Action Research with circles of thinking and reflection, to much more radical understandings of participation and knowledge, challenging traditional research practices in academia. This diversity shows that participatory approaches represent a broad and diverse type of methods that in different ways challenge Eurocentric assumptions to research but also work towards the advancement of decoloniality, as a way to pluralising our research processes in different forms and levels, as indigenous methodologies do.

Firstly, it focuses on decolonial issues such as domination, hegemony or epistemic injustices. Participatory approaches provide alternatives to research collaboratively and enable an adequate platform to include other knowledge systems. Secondly, it aims not only to emphases knowledge inequalities but also to challenge our understanding of what research is and for whom around the world and under different cosmovions. Thirdly, despite the Eurocentrism of our higher education institutions, participatory approaches can coexist and cohabit, even merge, with conventional research practices. This assists us in the diversification needed and the promotion of different approaches to research towards a genuine ecology of knowledges. And, fourthly, participatory approaches sustain key perspectives and values for the democratisation of knowledges, for instance, including participants as principal coresearchers of the process. 
The decolonial project, as a project towards a pluri-verse, requires the inclusion of participatory approaches - besides the use of indigenous/African methodologies - as a way to diversify the scientific field due to the fact that static, universal and inflexible methodologies are no longer adequate in our changing times (Lincoln, Lynham and Guba 2011). In conclusion, to increase and promote the use of participatory approaches, in combination with other alternatives ones - as indigenous methodologies - is necessary and urgent. It is, therefore, how we can cultivate and foster the open and innovative academic space required to promote the diversification needed to decolonise our hearts and our minds.

\section{CONCLUSION}

In this article, I have explored decolonial literature and how epistemic inequalities and injustices are reproduced by an unfair Western epistemic system. To understand these injustices, I have drawn on colonialism and modernism as the leading promoters of this epistemic structure and the actual consequences though the imperialist presentions of Europe and the West block. Hence, claiming a universal reality that is imposed on all as the only way to research. These ideas have shown that injustices, and more specifically, epistemic injustices are the consequences of this imperial system. It is a question of epistemic blindness, after all, jeopardising the valuable knowledge of many communities and societies around the world. In this line, scholars defended that there is a hegemonic block, pretending to universalised, their located understanding of reality. It is a geopolitical system mediated by power.

Further, I defended the need for a pluri-verse able to embrace other knowledge systems, instead of the actual uni-verse, where only Eurocentric knowledge is considered worth. Promoting a Pluri-verse, orienting our practices towards a pluri-versity of approaches would mean validating other knowledge systems, even the Eurocentric one. Plurality is not about changing one hegemonic system for a new one but promoting diversity and plural knowledges and transforming the inequalities that old unfair systems have caused.

I concluded that participatory approaches are in many ways imperfect practices, although heterogeneous, in the right direction to advance decolonisation, beside the use of indigenous/African methodologies. Participatory approaches possess a substantial potential towards decolonisation, forcing us to look for alternative solutions in an interconnected pluriversal world. Hence, although the pluri-versal project as a way of decolonisation is not a straight forward plan, either a clear succession of strategies; it does allow us to identify possible alternative that can be added to the current practices to promote the plurality and diversification needed to decolonise our higher education institutions and its research practices. 


\section{ACKNOWLEDGEMENTS}

I am indebted to Melanie Walker, Nelson Nkhoma and Mikateko Hoppener for their helpful comments into this article and our conversations about my work. I also acknowledge NRF Grant no. 86540, which funded my research under the SARCHI Chair in Higher Education and Human Development.

\section{NOTE}

1. For more information, see De Sousa Santos $(2010,56)$.

\section{REFERENCES}

Adelman, Clem. 1993. Kurt Lewin and the origins of action research. Educational action research 1(1): $7-24$.

Appiah, Anthony. 1993. In my father's house: Africa in the philosophy of culture. OUP USA.

Appiah, Kwame. 2010. "Europe upside down." Perspectives on Africa: A reader in culture, history and representation, 48-54. West Sussex: United Kingdom. Wiley-Blackwell Publishing.

Becker, Heike. 2016. South Africa's May 1968: Decolonising institutions and minds. Review of African Political Economy. University of the Western Cape repository. https://repository.uwc.ac.za/ bitstream/handle/10566/3130/Becker-South-Africa_2016.pdf?sequence=1\&isAllowed=y

Boidin, Capucine, James Cohen and Ramón Grosfoguel. 2012. Introduction: From university to pluriversity: A decolonial approach to the present crisis of western universities. Human Architecture: Journal of the Sociology of Self-Knowledge 10(1): 2.

Bosch, Tanja. 2017. Twitter activism and youth in South Africa: The case of \#RhodesMustFall. Information, Communication \& Society 20(2): 221-232.

Brydon-Miller, Mary. 2001. Education, research, and action: Theory and methods of participatory action research. From subjects to subjectivities: A handbook of interpretive and participatory methods, 76. NewYork, US: New York University Press

Castells, Manuel. 2001. Challenges of globalisation: South African debates with Manuel Castells. Vol. 4. Pearson South Africa.

Castro-Gomez, Santiago. 2000. Ciencias sociales, violencia epistémica y el problema de la "invención del otro". La colonialidad del saber: Eurocentrismo y ciencias sociales. Perspectivas latinoamericanas, 145-161. Buenos Aires, Argentina: Ediciones Faces/UCV

Césaire, Aimé. 2001. Discourse on colonialism. New York, US: NYU Press.

Chilisa, Bagele. 2012. Indigenous research methodologies. Los Angeles, U.S: Sage Publications.

Dash, D. P. 1999. Current debates in action research. Systemic Practice and Action Research 12(5): 457-492.

Dei, George J. Sefa. 2014. Indigenizing the curriculum: The case of the African university. In African indigenous knowledge and the disciplines, 165-180. Brill Sense.

De Sousa Santos, Boaventura. 2006a. Conocer desde el Sur: Para una cultura política emancipatoria. Lima, Peru: UNMSM.

De Sousa Santos, Boaventura. 2006b. La universidad popular del siglo XXI. Fondo Editorial de la Facultad de Ciencias y Sociales. UNMSM, Lima.

De Sousa Santos, Boaventura. 2010. Descolonizar el saber, reinventar el poder. Montevideo, Uruguay: EdicionesTrilce.

De Sousa Santos, Boaventura. 2012. The university at a crossroads. Human Architecture: Journal of the 
Sociology of Self-knowledge 10(1): 3.

De Sousa Santos, Boaventura. 2015. Epistemologies of the South: Justice against epistemicide. New York, U.S.: Routledge.

Derrida, Jacques. 2003. Márgenes de la filosofia, trad. Carmen González Marín, Cátedra, Madrid.

Diop, Cheikh Anta. 2010. The meaning of our work. Perspectives on Africa 2010: 44-47.

Dussel, Enrique. 1994. Historia de la filosofía y filosofía de la liberación. Ciudad de Mexico, Mexico: Editorial Nueva América.

Dussel, Enrique. 2000. Europa, modernidad y eurocentrismo. En libro: La colonialidad del saber: eurocentrismo y ciencias sociales. Perspectivas Latinoamericanas. Edgardo Lander (Comp.) CLACSO, Buenos Aires, Argentina.

Dussel, Enrique D. 2007. Materiales para una política de la liberación. Madrid: Espana. Plaza y Valdes Editores.

Emeagwali, Gloria and George J. Sefa Dei. 2014. African indigenous knowledge and the disciplines. Rotterdam, The Netherlands: Sense Publishers.

Escobar, Arturo. 2007. Worlds and knowledges otherwise: The Latin American modernity/coloniality research program. Cultural Studies 21(2-3): 179-210.

Escobar, Arturo. 2018. Designs for the pluriverse: Radical interdependence, autonomy, and the making of worlds. Durham, US: Duke University Press.

Fanon, Frantz. 2007. The wretched of the earth. New York, U.S: Grove/Atlantic, Inc.

Fals-Borda, Orlando and Muhammad Anisur Rahman. 1991. Action and knowledge: Breaking the monopoly with participatory action-research. London, United Kingdom: Intermediate Technology.

Feldman, Allan. 2017. An emergent history of educational action research in the English-speaking world. In The Palgrave international handbook of action research, 125-145. Palgrave Macmillan, New York.

Foucault, Michel. 1982. The subject and power. Critical Inquiry 8(4): 777-795.

Foucault, M. 2002. The order of things: An archaeology of the human sciences. London, U.K.: Psychology Press.

Gazda, G. M., D. A. Kipper and T. W. Treadwell. 1997. A message from the executive editors. Int. J. Act. Methods Psychodrama Skill Train. Role Play 50(1): 3.

Girei, Emanuela. 2017. Decolonising management knowledge: A reflexive journey as practitioner and researcher in Uganda. Management Learning 48(4): 453-470.

Greenwood, Davydd J. and Morten Levin. 2007. Introduction to action research: Social research for social change. California, U.S.: SAGE publications.

Hall, Budd L. and Rajesh Tandon. 2017. Decolonization of knowledge, epistemicide, participatory research and higher education. Research for All 1(1): 6-19.

Hlela, Zamokwakho. 2016. Learning through the action of research: Reflections on an Afrocentric research design. Community Development Journal 53(2): 375-392.

Kindon, Sara, Rachel Pain and Mike Kesby. 2007. (Eds.). Participatory action research approaches and methods: Connecting people, participation and place. New York, U.S.: Routledge.

Kristiansen, Marianne, and Jørgen Bloch-Poulsen. 2016. Participatory hierarchies: A challenge in organisational Action Research. International Journal of Action Research 12(2).

Lander, Edgardo. 2000. Ciencias sociales: Saberes coloniales y eurocéntricos. Buenos Aires, Argentina: Clacso.

Lincoln, Yvonna S., Susan A. Lynham and Egon G. Guba. 2011. Paradigmatic controversies, contradictions, and emerging confluences, revisited. The Sage handbook of qualitative research 4: 97-128. Sage Publications. 
Luescher, Thierry, Lacea Loader and Taabo Mugume. 2016. \#FeesMustFall: An Internet-age student movement in South Africa and the case of the University of the Free State. Politikon 44(2): 231245.

Mbembe, Achille. 1992. Provisional notes on the postcolony. Africa 62(1): 3-37.

Mbembe, Achille. 2011. Necropolítica: Seguido de Sobre el gobierno privado indirecto. Buenos Aires, Argentina: Melusina.

Mignolo, Walter D. 2000. La colonialidad a lo largo ya lo ancho: El hemisferio occidental en el horizonte colonial de la modernidad. Durham, US: Duke University Press

Mignolo, Walter D. 2007. Delinking: The rhetoric of modernity, the logic of coloniality and the grammar of de-coloniality. Cultural studies 21(2-3): 449-514.

Naicker, Camalita. 2016. From Marikana to \#feesmustfall: The praxis of popular politics in South Africa. Urbanisation 1(1): 53-61.

Noffke, Susan and Bridget Somekh. 2009. The SAGE handbook of educational action research. London, U.K.: Sage Publications.

Nyemba, Florence and Minna Mayer. 2017. Exploring the roots of participatory action research: An interview with Dr. Marja-LiisaSwantz. Action Research 16(3): 319-338.

Obiokor, Paul. 2014. Art education: Curriculum, traditional knowledge and practice in Nigeria. In African indigenous knowledge and the disciplines, 99-111. Brill Sense.

Parra-Romero, Adela Parra. 2016. ¿ Por qué pensar un giro decolonial en el análisis de los conflictos socioambientales en América Latina?. Ecologíapolitica 51: 15-20.

Ranger, Terence. 1997. The invention of tradition in colonial Africa. Perspectives on Africa: A reader in culture, history, and representation, 597-612.

Rappaport, Joanne. 2017. Participation and the work of the imagination: A Colombian retrospective. In The Palgrave international handbook of action research, 147-159. Palgrave Macmillan, New York.

Riley, J. C. 2001. Rising life expectancy: A global history. Cambridge, U.K.: Cambridge University Press.

Shizha, Edward. 2014. The indigenous knowledge systems and the curriculum. In African indigenous knowledge and the disciplines, 113-129. Brill Sense, 2014.

Semali, Ladislaus M. and Joe L. Kincheloe. 2002. What is indigenous knowledge?: Voices from the academy. Quebec, Canada: Routledge.

Soldatenko, Gabriel. 2015. A contribution toward the decolonization of philosophy: Asserting the coloniality of power in the study of non-western philosophical traditions. Comparative and Continental Philosophy 7(2): 138-156.

Smith, L. T. 1999. Decolonizing methodologies: Research and indigenous peoples. Zed Books Ltd: London, UK.

Thiollent, Michel and Maria Madalena Colette. 2017. Action research and participatory research in Brazil. In The Palgrave international handbook of action research, 161-176. Palgrave Macmillan, New York.

Wa Thiong'o, Ngugi. 1994. Decolonising the mind: The politics of language in African literature. London, U.K.: East African Educational Publishers.

Whitt, Laurelyn. 2009. Science, colonialism, and indigenous peoples: The cultural politics of law and knowledge. Cambridge University Press.

Zaffaroni, E. R. 2012. La Pacha Mama y el Humano. Buenos Aires, Argentina: Colihue y Madres de Plaza de Mayo.

Zibechi, Raúl. 2015. Descolonizar el pensamiento crítico y las prácticas emancipatorias. Buenos Aires, Argentina: Ediciones Desde Abajo. 